\title{
The Revised Guidelines on Bancassurance Operation in Nigeria: Marketing Implications on Patronage of Insurance Products
}

\author{
Nebo Gerald Nwora $(\mathrm{PhD})$ \\ Department of Marketing, Enugu State Univ. of Science \& Technology, Enugu State, Nigeria \\ E-mail: geraldnebo@yahoo.com
}

Received: December 13, 2018 Accepted: December 23, 2018 Published: December 23, 2018

doi:10.5296/jpmr.v4i2.14102 URL: http://dx.doi.org/10.5296/jpmr.v4i2.14102

\begin{abstract}
This study seeks to assess the marketing implication of the revised operational guidelines on bancassurance referral model in Nigeria particularly in terms of how the model can affect customers' patronage of Insurance companies. The objectives of the study include; (i) to determine the influence of bancassurance referral on customers' patronage of insurance products; (ii) to ascertain how customer loyalty moderate the influence of bancassurance referral on customers' patronage of insurance products; and (iii) to assess how the perceived service quality of the deposit money banks moderate the influence of bancassurance referral on customers' patronage of the insurance products. Quantitative survey research design was adopted for the study. By gathering primary data from 170 banks' customers and 68 bancassurance desk officers of insurance companies using structured questionnaire; and using structural equation modelling for testing and analyzing the gathered datasets, findings revealed that bancassurance referral model has significant influence on customers' patronage of insurance products and both customer loyalty and perceived service quality of the banks significantly moderate the influence of bancassurance referral model on customers' patronage of the insurance products. It was recommended that insurance companies that want to go into bancassurance relationship with any bank in Nigeria should choose banks characterized by large number of loyal customers and high perceived service quality.
\end{abstract}

Keywords: Bancassurance, customer loyalty, customer patronage, perceived service quality

\section{Introduction}

Insurance is a policy designed to indemnify the insured against all sums for which the insurer is legally liable upon receipt of premium by the insurer in occurrence of the peril insured against. By its nature the insurance sector is expected to provide a relief to the effects of risks 
such as illness, accident, death, fire, burglary, price fluctuations, natural disaster for which we have no control (Nebo \& Okolo, 2014). The sector is also expected to complement the banking sector in the development of other sectors in the economy such as telecommunications, transportation, agriculture, manufacturing, commerce and services by absorbing business risks, providing easy access to credit and channelling savings into long-term investments. On the contrary, the industry has not been performing as expected in Nigeria. Ighomirenghian (2010) and Johri (2009) lament that the insurance sector in Nigeria is characterized by its inability to attract sufficient businesses both locally and internationally due to its low underwriting capability compared to available risks. Other problems of the industry include: poor public image and perception, weak distribution channels, defaults in payments of premium, low investment, unethical practices, lack of skilled personnel, poor corporate governance and management (Nebo \& Okolo, 2014; Ighomirenghian, 2010; Johri, 2009).

In order to improve and reverse the declining public confidence in the sector, the federal government has put in place a number of measures. First it empowers the National Insurance Commission (NAICOM) through the National Insurance Commission Act of 1997 and the Insurance Act of 2003 to regulate the activities of all insurance companies in Nigeria by issuing laws, policies, rules and sanctions that guide actions in the industry. All insurance firms operating in Nigeria must be licensed by NAICOM. Secondly, the industry has undergone double recapitalization exercise. The first was in 2003 and the second was in September, 2005.

Thirdly, and the latest exercise was through bancassurance referral practices which is the focus of this study. Many years ago the business of deposit money banks (formerly known as commercial banks) and insurance companies in Nigeria have been known to be distinct from each other and operated fence to fence (Ayadi, 2014), however, through the reform exercise of the insurance sector by the Central Bank of Nigeria, insurance firms were allowed to collaborate with deposit money banks for business under a statutorily defined referral model called bancassurance (CBN, 2017; NAICOM, 2017). New guidelines for such collaboration (i.e bancassurance practice) was issued by the Central Bank of Nigeria and this took effect from $1^{\text {st }}$ April, 2017.

Bancassurance is basically the strategy of using bank branches as a medium for distributing insurance products (Genetay \& Molyneux, 1998). It is regarded as a collaboration between bank and insurer to market or distribute insurer's products to bank customers. Insurer (i.e the insurance company) provides the insurance products and services while bank acts as the distributors. Level of bank and insurance collaboration can vary from basic to high level integration depending on the financial guidelines of each country. The common argument for adopting bancassurance is to help insurance companies to sell their products through the bank's already established customer relationship, customer database and branch networks.

In Nigeria the level of collaboration between bank and insurance companies is just on referral basis. It is stated clearly in the section 4 (2) of new 2017 CBN's bancassurance revised guidelines that no Nigerian bank shall undertake any insurance marketing, sales or services other than to refer their customers to insurance companies. Deposit money banks are to act on 
reference basis only. In order to avoid the confusion pertaining to the true providers of the insurance products, in the 2017 CBN's revised guidelines, banks were prohibited from direct sales of insurance products to the customer or using any form of radio, television, newspaper, billboard, handbills, internet advertisements to inform or educate its customers about insurance services (CBN, 2017). This means that banks should only direct or link its customers to insurance firms for provision of insurance services. Bancassurance strategy provides benefits for both bank and insurance companies. While the referral banks get paid for every successful closed lead made, insurance companies capitalizes on the banks' good perceived image, large customer databases and large branch networks to make more sales of their products.

Although the idea of bancassurance is relatively new in Nigeria, it has been in existence in other parts of the world such as Australia, Belgium, Brazil, Chile, France, Italy, Tunisia, Pakistan, Malaysia, Spain, U.S and several other countries (Ricci, 2012). It first started in France and today, it has spread all over the world (Ricci, 2012).

Since the emergence of bancassurance, several studies have been done to pin-point the benefits, efficiency and profitable economies of scope inherent in the collaborative efforts of banks and insurance companies including increase in productivity (Chen et al., 2006; Casu \& Girardone, 2004; Fields et al., 2004). Past studies also show that bancassurance increases the sales of both banks and insurance companies (Karimian, 2017). Other scholars argue that with bancassurance, there is tendency to achieve reduced distribution cost on insurance products compared to when the distribution channel was left with insurance companies only (Chen et al., 2006). Collaborations between banks and insurance companies (i.e bancassurance) is gradually gaining attention in Nigeria. This business concept has introduced radical changes in the banking and insurance business landscape which managers cannot afford to ignore and its true benefits is yet to be ascertained in Nigeria just like in other parts of the world.

Additionally, some scholars argue that the loyalty and perceived service quality of the banks' customers may moderate the extent to which the banks successfully refer their customers to insurance products (Kiragu, 2014; Loveline \& Sreedevi, 2014). This means that customers that are loyal to a bank may extend their patronage or loyalty to insurance companies whose products they are referred to. Similarly, the bancassurance referral influence of a bank depends majorly on the perceived service quality of the banks' customers. For instance, if existing customers of a bank have poor perception about the service quality of the bank, this may further affect their patronage of insurance products the bank may refer them to.

Although research studies on bancassurance have been in existence in other parts of the world; this business concept is relatively new in Nigeria and its marketing implications is yet to be ascertained (Ricci, 2012). Now that the concept is beginning to introduce changes and redefine insurance business landscape; there is the need to determine its marketing implications especially its effects on customers' patronage of insurance products. From previous studies, it appears that the influence of bancassurance on insurance product patronage is highly under-reported in Nigerian context. More importantly, there is little or no empirical research works in the Nigerian context to determine the moderating influence of 
customer loyalty and service quality on the relationship between bancassurance and customers' patronage of insurance products. Consequently this study makes contribution to bancassurance theory and also tries to:(i) determine the influence of bancassurance referral on customers' patronage of insurance products; (ii) ascertain how customer loyalty moderate the influence of bancassurance referral on customers' patronage of insurance products; and (iii) assess how the perceived service quality of the deposit money banks moderate the influence of bancassurance on customers' patronage of insurance products

\section{Review of the Literature}

\subsection{Conceptual Clarification of the Meaning of Bancassurance}

Bancassurance first originated in France in the 1980, spread across Europe rapidly and later on to other parts of the world. Although, the term was coined from 'bank' and 'insurance', there is no consensus among scholars in the literature regarding the meaning of bancassurance. Many of the contributors to the growing discourse on the concept are country specific in their focus and each describes bancassurance concept as it applies to their home countries (Waweru, 2014; Ayadi, 2014). Diverse terminologies have been used to describe bancassurance concept including 'Allfinance' (in German), 'Assurebanking', and 'Integrated Financial Service' all of which refer to the delivery of banking and insurance products under one roof One school of thought present bancassurance as a diversification strategy which banks adopt by undertaking insurance business with their core banking business (Chen et al., 2006; Brealey \& Myers, 2003; Jongeneel, 2011), while another school present it as an alternative distribution channel through which insurance products are marketed. Some other scholars think of bancassurance from the perspective of mergers and acquisitions between banks and insurance companies (Chen et al., 2006). Central Bank of Nigeria (2017) refers to bancassurance as an arrangement in which insurance companies leverage on the customer base of banks to sell insurance products to banks' customers. Some authors refer to it as a one-stop shopping form of business deal between banks and insurance companies such that the banks sells insurance products.

Although various opinion exist about the meaning of bancassurance, most scholars commonly define it as the distribution of insurance products through banking channels. Bancassurance means the collaboration between a bank and an insurance company to market insurance products to the customers of the bank. The insurance company provides the products while the bank provides the distribution channels or outlets. The level of collaboration between banks and insurance firms can vary from basic level to high level integration depending on the country's financial guidelines.

In Nigeria the concept is somewhat different and the level of collaboration is stipulated in the new 2017 CBN's revised guidelines for bancassurance operations. This guidelines strictly specify non-inclusion of the deposit money banks in the marketing of insurance products except to just refer their customers to products of insurance company partnering with the bank. In the context of this study, bancassurance is conceptualized as a strategy whereby an insurance company capitalizes on the large customer base and branch network of deposit money banks to sell its products to bank customers. 


\subsection{The Growth of Bancassurance}

Prior to the development and introduction of bancassurance strategy, the financial sector has always been the growth engine for all countries but the worrisome performance of the players in the sector (i.e. banks and insurance subsectors) arising from their weak capital base, poor asset quality and increased liquidations prompted the concerns that led to the reform of the sector. The insurance sector in particular faced a worrisome snail speed growth and poorly mature markets. Nigeria is not exempted from this experience. This is what gave rise to various reform exercises in the industry including the 2005 recapitalization policy.. In the aftermath of the reform, the need for growth and survival coupled with globalization and changes in customers demand have been accounted for as the reason that provoked the emergence of financial conglomeration which resulted in Bancassurance (Karunagaran, 2006).

To some researchers, the term bancassurance is said to have been first coined in Britain in 1965 when a subsidiary of Barclays, Barclays Life was dropped for poor performance. Whereas some said it originated first in France in the 1970s in the bid to remove the involvement of middlemen in loan protection insurance and later in Spain in the 1980s (Waweru, 2014). Regardless of where it first originated, bancassurance became a popular strategy for operating both insurance and banking business with a symbiotic relationship in Europe and gradually was spread to all other parts of the world.

The major reason for bancassurance was borne out of the need to develop the insurance sector, which has suffered image problem in recent times especially in Nigeria. This underlies Florido's (2002) analytical meaning which interprets bancassurance as "banque or bank" and "assurance" - signifying that both insurance and banking products are offered by the same corporate entity. The existing literature on this area of study shows that the most common debated basis for adopting bancassurance today is to allow insurance companies to sell their products through the banks' already established customer relationship, customer database and branch networks. However this has been misinterpreted or misconstrued by some scholars as merger and acquisition relationship or diversification strategy for banks into insurance business.

\subsection{The Revised Guidelines to Bancassurance Referral Model}

The Central Bank of Nigeria (CBN), in exercise of its power under section 33(1)b of CBN Act 2007 including its provision of part 2 section 3(1) of the CBN scope, condition and minimum standards for commercial banks regulation no. 1, 2010, issued some revised guidelines on the operation of bancassurance between Nigerian money deposit banks and insurance companies. In confirmation of this scheduled revise guidelines, National Insurance Commission (NAICOM) which regulate insurance practices in Nigeria also reissued the CBN's guidelines for use by insurance companies. Section 4(2) of the CBN's guidelines as well as section 6.2.1 of the NAICOM's attested CBN's guidelines and both specify clearly that no Nigerian bank shall undertake any insurance marketing, sales or service other than to make referral only. However, from the glossary of operationalized terminologies provided in the CBN and NAICOM's revised guidelines, the definition of the concept of bancassurance 


\section{Macrothink

which is expected to guide the operations of banks and insurance is somewhat contradictive. For instance, CBN (2017) defines it as "an arrangement in which insurance companies leverage on the customer base of banks to sell insurance products to banks' customers" whereas NAICOM (2017), in the bid to simplify CBN's revised guidelines sees it as "the collaboration between a bank and an insurance company to market insurance products to the customers of the bank". Now, contrasting these two definitions, it would be inferred that both CBN and NAICOM still have some differing views regarding the extent of banks' involvement or collaborations in the marketing of insurance products. Meanwhile, going by section 6.2.3 of the NAICOM's and section 6(4) of the CBN's guidelines, it is clearly stated that all referral banks shall not use any advertisement or promotion whatsoever like in kinds of logo or signature which may confuse prospective customers about the actual provider of the insurance service. Banks are not allowed to deeply engage in marketing of insurance products except to refer its customers to partnering insurance firms that often maintain a desk officer within the bank. From these deductions, it can be said that the new 2017 revised guidelines cast doubts on the capability of bancassurance referral model to influence bank customers' patronage of the insurance companies.

\subsection{Conceptual Framework and Hypotheses Development}

Figure 1 below represents the conceptual framework guiding this study.

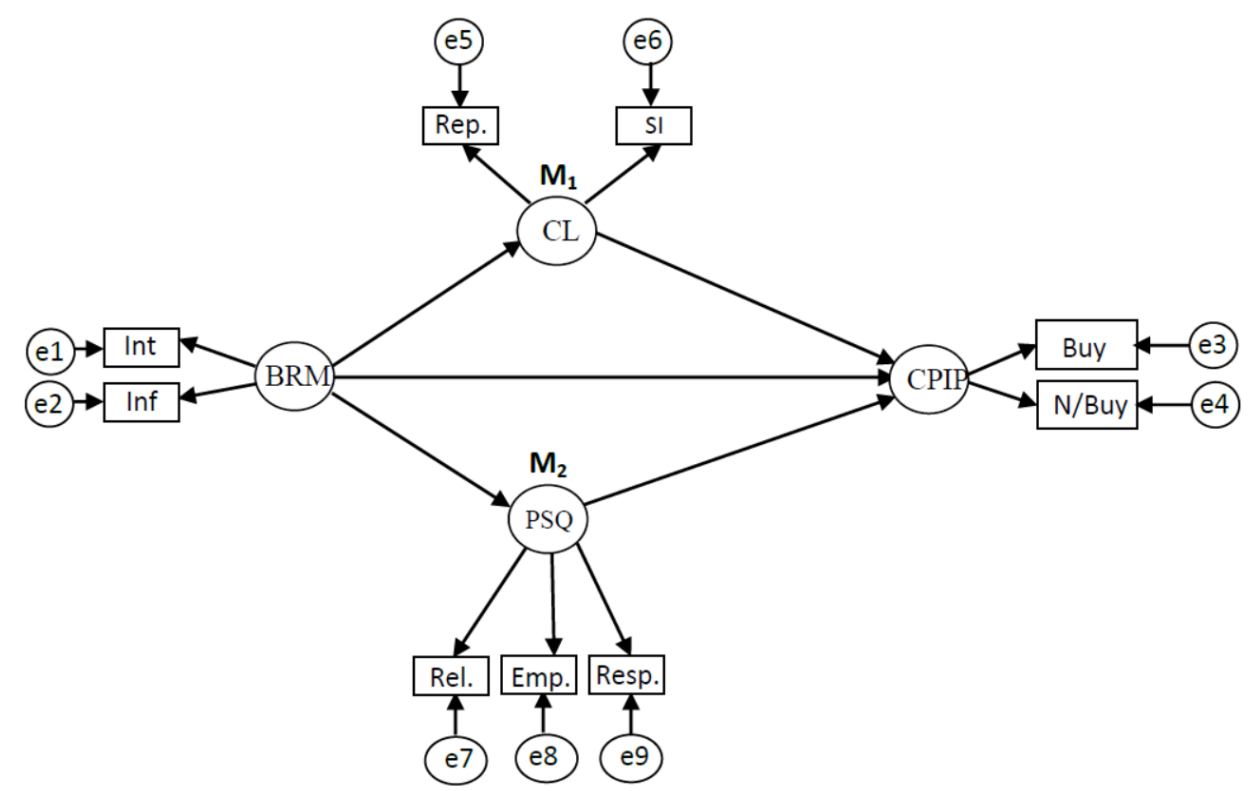

$\begin{array}{ll}\text { BRS }= & \text { Bancassurance Referral Model } \\ \text { Int }= & \text { Introduce Customers to Insurance Companies } \\ \text { Inf }= & \text { Inform Customers about Insurance Products } \\ \text { PSQ }= & \text { Perceived Service Quality } \\ \text { Rel. }= & \text { Reliability } \\ \text { Emp. }= & \text { Empathy } \\ \text { Resp. }= & \text { Responsiveness }\end{array}$

$\begin{array}{ll}\text { CL }= & \text { Customer Loyalty } \\ \text { Rep }= & \text { Repurchases } \\ \text { SI }= & \text { Switching Intention }\end{array}$

Source: Researcher's intuition

CPIP = Customer Patronage of Insurance Products

Buy $=\quad$ Will Buy Insurance Product

N/Buy $=$ Will Not Buy Insurance Products 


\section{Bancassurance Referral Model (BRM) and Customers' Patronage of Insurance Products (CPIP)}

According to the CBN's 2017 revised guidelines, bancassurance referral mode is a special type of business corroboration between deposit money banks and insurance companies, whereby banks are not allowed to add insurance services to their product line or sell, advertise or market insurance products directly to customers but are only allowed to refer their customers to a reliable insurance company which maintain relationship with the bank. The insurance company provides the products while the bank only refers or links its customers to them. Specifically, the CBN's 2017 revised bancassurance model requires that deposit money banks staff shall only orally (i) inform their customers about insurance products and (ii) introduce or refer them to the desk officer of a reliable insurance company assigned to partner with the bank under the same roof for insurance services. Bancassurance model strictly specifies that deposit money banks should not participate in the direct marketing of insurance products except to just refer their customers to products of their partnered insurance companies. Bancassurance is a strategy of using banks as channel intermediaries acting in agent capacity for distributing insurance products. They merely link their customers with a specific insurance company operating under the same roof with the bank for insurance businesses. It is an arrangement in which insurance companies capitalize on the large customer base of the bank to sell insurance products to bank customers (CBN, 2017; NAICOM, 2017).

A customer is said to patronize insurance products when he/she has either actually bought insurance products or has the intention of buying it. Customer patronage for insurance products is determined by (i), customer's willingness to purchase insurance products (ii) customer's unwillingness to buy the product. Bancassurance referral model has been found to influence bank customers' patronage for insurance products. For instance, Mwangi (2010) reports that the addition of insurance products to core banking business in Kenya and making customers to get related services under one roof are factors that led to increase in the purchase of insurance products. Similarly, Chen et al.'s (2006) studies also confirm that bancassurance increases the sales of both banks and insurance companies. Additionally, in the new 2017 revised guidelines where banks are not allowed to deeply engage in marketing of insurance products except to refer its customers to partnering insurance firms cast doubts on the capability of bancassurance referral model to influence bank customers' patronage of the insurance companies. On the basis of this argument, this study hypothesises that:

$\mathrm{H}_{1}$ : Bancassurance referral model has a significant positive influence on customers' patronage of insurance products in Nigeria

\section{Customer loyalty moderate the relationship between bancassurance referral model and customers' patronage of insurance products.}

Customer loyalty has been described in various ways. Some describe it as a measures of how likely customers are to return to a particular product or organization for business. The customer's expectations must be met or exceeded in order to build loyalty. Customer loyalty is measured by (i), repeat purchases by the customer (ii) customer's switching intensions and 
(iii) customer's willingness to spread positive word-of-mouth or recommend the product to others (Kotler et al 2010). Customer loyalty has been found to influence the relationship between bancassurance and customers' patronage of insurance products. Scholars believe that customers' loyalty to a bank will influence the extent to which banks can successfully refer them to insurance firms for purchases (Loveline \& Sreedevi, 2014). Non-loyal bank customers may be difficulty to refer to insurance companies for product patronage. Based on this discussion, this study hypothesises that:

$\mathrm{H}_{2}$ : Customer loyalty significantly mediate the influence of bancassurance referral model on customers' patronage of insurance products in Nigeria.

\section{Service quality moderate the relationship between bancassurance referral model and customers' patronage of insurance products.}

Customers perceived service quality is the degree of discrepancy between customers' normative expectation for service and their perceptions of the actual service delivered. It is an evaluation made by the customer between the values he/she expects from a service and the actual perceived service delivered (Kotler et al., 2010).

Scholars have different views about dimensions or measures of customer service quality. However, most agree on service quality measures postulated by Parasuraman, (1988). These are: reliability, assurance, tangibility, empathy and responsiveness of the service provider. For the purpose of this study, the researcher concentrated on three major service quality variables which mostly apply to banking industry. These are: reliability, empathy and responsiveness. Reliability, refers to the service provider's ability to perform the promised service dependably and accurately. Empathy refers to service provider's ability to understand the customer's needs. Empathy is determined by three major things. These are (i) ease of contact and approachability of the service provider (ii) ability of the service provider to listen to customers and keep them informed and (iii) making efforts to understand customers and their needs. Responsiveness is the willingness of the service provider to help customers and provide prompt service (Lovelock \& Wirtz, 2014)

A critique of bank referral model believe that a deposit money bank may not successfully refer its customers to an insurance firm for business if the service quality of such bank doing the referral is poor (Kiragu, 2014; Loveline \& Sreedevi, 2014). In order words, the influence of bancassurance referral on customers' patronage of insurance products is moderated by the bank's perceived service quality. It is on this basis we postulated that:

$\mathrm{H}_{3}$ : Service quality significantly mediate the influence of bancassurance referral model on customers' patronage of insurance products in Nigeria.

Drawing from the above arguments about the influence of bancassurance referral model on customers patronage of insurance product (see path BRM $\longrightarrow$ CPIP) in figure 1, this path may be moderated by two intervening marketing variables, (i) customer loyalty $\left(\mathrm{M}_{1}\right)$ and/or (ii) perceived service quality $\left(\mathrm{M}_{2}\right)$. (See figure 1 above) 


\section{Methodology}

Quantitative survey research design methodology was adopted for this study. This is consistent with hypothesis testing and generalization of results (Hair et al., 2011). The unit of analysis for this study were the bank customers (18 years and above) and insurance desk officers drawn from the seventeen (17) deposit money banks and insurance companies partners operating within Enugu metropolis. A sample size of 170 bank customers and 68 insurance desk officers were used for the study. There are two reasons for focusing on the sample of customers 18 years and older, and insurance officers. First, bank customers and insurance desk officers were the focus of bancassurance referral model. Second, customers 18 years and above in the Nigerian context are adults and are considered to have capacity for independent decision. Enugu state was also chosen for the study because it is the capital of South-East geo-political of Nigeria and most deposit money banks locate their regional headquarters there.

The questionnaire was the major instrument used for collecting primary data. The questions were divided into five sections. Section A captured the demographic data of the respondents, section B to E contain questions on the major variables or constructs under investigation. Specifically, section B captured questions on measurement scales and items for bancassurance (independent) variables which were developed from extant literature (CBN, 2017; NAICOM, 2017). Section C contains questions on measurement scales/items for customer loyalty (moderating) variable which were developed from extant literature (Kotler, 2010). Section D contains questions items for service quality (moderating) variable adapted from Parasuraman et al's (1988) model and Lovelock and Wirtz's (2014) study. Section E captured questions on measurement scales/items for customer patronage (dependent) variable adapted from Nebo and Okolo's (2016) study.

All question items were measured in a 5 -point Likert scale ranging from strongly agree (5) to strongly disagree (1). Identical questions were asked to both bank customers and insurance desk officers that collaborate with the banks.

Prior to distributing the questionnaire to the respondents, face validity was checked using two experienced senior academic marketing researchers. The content validity was also checked by ensuring that the questionnaire items were constructed in line with the research objectives and measurement scales developed from the literature and previous studies. Secondly, instrument was also pre-tested using 30 potential bank customers and insurance company desk officers each. The pre-test was to detect potential errors relating to wordings, format and contents of the instrument as well as ensuring that the respondents understand the meanings of each construct's items before its actual distribution. The reliability of the instrument was also checked using Cronbatch alpha test. The results indicated alpha values of 0.73 and 0.83 for both consumers' and insurance staff questionnaires respectively. Thus the instrument were deemed reliable based on DeVellis's (1991) minimum benchmark of 0.65 alpha coefficient.

Copies of the questionnaire were self-administered in all the 17 deposit money banks branches and insurance companies operating within the selected bank branches in Enugu metropolis. Convenience sampling techniques was adopted for selecting the respondents that 
completed the questionnaire. The datasets gathered were analysed using structural equation modelling through Amos version 25.0 with maximum likelihood estimation.

\section{Data Presentation and Analysis}

Table 1. Demographic Profile and Sample Descriptive Statistics

\begin{tabular}{|c|c|c|c|c|}
\hline & \multicolumn{2}{|c|}{ Customers } & \multicolumn{2}{|c|}{ Bancassurance Desk Officers } \\
\hline Gender & Frequency & Percent & Frequency & Percent \\
\hline Male & 83 & $61.9 \%$ & 19 & $35.8 \%$ \\
\hline Female & 51 & $38.1 \%$ & 34 & $64.2 \%$ \\
\hline Total & 134 & $100.0 \%$ & 53 & $100.0 \%$ \\
\hline \multicolumn{5}{|l|}{ Age } \\
\hline$\geq 45 \mathrm{yrs}$ & 30 & $22.4 \%$ & 2 & $3.8 \%$ \\
\hline $35-44 y r s$ & 65 & $48.5 \%$ & 12 & $22.6 \%$ \\
\hline $25-34 y r s$ & 28 & $20.9 \%$ & 31 & $58.5 \%$ \\
\hline$<25 \mathrm{yrs}$ & 11 & $8.2 \%$ & 8 & $15.1 \%$ \\
\hline Total & 134 & $100.0 \%$ & 53 & $100.0 \%$ \\
\hline \multicolumn{5}{|l|}{ Marital Status } \\
\hline Married & 117 & $87.3 \%$ & 32 & $60.4 \%$ \\
\hline Single & 17 & $12.7 \%$ & 21 & $39.6 \%$ \\
\hline Total & 134 & $100.0 \%$ & 53 & $100.0 \%$ \\
\hline \multicolumn{5}{|c|}{ Education Qualification } \\
\hline Ph.D & 8 & $6.0 \%$ & 0 & $0.0 \%$ \\
\hline Master & 49 & $36.6 \%$ & 7 & $13.2 \%$ \\
\hline $\mathrm{BSc} / \mathrm{HND}$ & 67 & $50.0 \%$ & 46 & $86.8 \%$ \\
\hline OND/NCE/O'Level & 10 & $7.5 \%$ & 0 & $0.0 \%$ \\
\hline Total & 134 & $100.0 \%$ & 53 & $100.0 \%$ \\
\hline
\end{tabular}

Source: Field Survey, 2018

Table 1 shows that majority of the bank customers (61.9\%) are males while majority of the bancassurance desk officers $(64.2 \%)$ are females. As for their age distributions, majority of the customers $(48.5 \%)$ are between 35 - 44years old while majority of the bancassurance desk officers (58.5\%) are between 25 - 34years old. In terms of marital statuses, majority of the customers $(87.3 \%)$ and desk officers $(60.4 \%)$ are married. The educational qualifications 
show that majority of the bank customers (50\%) and bancassurance desk officers $(86.8 \%)$ hold BSc/HND certificates.

Analysis and tests of hypotheses in this study were utilized by using Structural Equation Modeling (SEM). The test was run on AMOS version 25.0 with maximum likelihood estimation.

Table 2. Correlations, Mean, Standard Deviation, and Square Root of AVE

\begin{tabular}{ccccc}
\hline Constructs & $\begin{array}{c}\text { Bancassurance } \\
\text { Referral Model }\end{array}$ & $\begin{array}{c}\text { Customer } \\
\text { Loyalty }\end{array}$ & $\begin{array}{c}\text { Perceived } \\
\text { Service Quality }\end{array}$ & $\begin{array}{c}\text { Customer Patronage } \\
\text { Insurance Products }\end{array}$ \\
\hline BRM & .874 & & & \\
CL & $.538^{* *}$ &. $\mathbf{7 8 9}$ & .865 & \\
PSQ & $.814^{* *}$ & $.403^{*}$ & $.869^{* *}$ & $\mathbf{. 6 1 5}$ \\
CPIP & $.602^{*}$ & $.309^{* *}$ & .773 & 4.72 \\
Mean & 4.37 & 4.25 & .8223 & .5921 \\
Std Dev. & .6927 & .7355 & & .823 \\
\hline
\end{tabular}

$* \mathrm{p}<0.05, * * \mathrm{p}<0.01$

Table 2 above presents the mean, standard deviation, correlation and square root of average variance extracted (AVE). All the variables had significant positive inter-item correlations with Customer Patronage of insurance products (CPIP).

Table 3. Factor Loading ( $\boldsymbol{\lambda})$, Cronbach's ( $\boldsymbol{\alpha})$, AVE and Composite Reliability

\begin{tabular}{|c|c|c|c|c|c|c|}
\hline Constructs & Items & $\lambda$ & $\begin{array}{c}\text { Cronbach's } \\
\boldsymbol{\alpha}\end{array}$ & AVE & $\begin{array}{c}\text { Square Root } \\
\text { of AVE }\end{array}$ & $\begin{array}{l}\text { Composite } \\
\text { Reliability }\end{array}$ \\
\hline $\begin{array}{l}\text { Bancassurance } \\
\text { Referral Model }\end{array}$ & $\begin{array}{l}\text { Int. } \\
\text { Inf. }\end{array}$ & $\begin{array}{r}.766 \\
.913\end{array}$ & .872 & .849 & .874 & .803 \\
\hline $\begin{array}{l}\text { Customer } \\
\text { Loyalty }\end{array}$ & $\begin{array}{c}\text { Rep } \\
\text { SI }\end{array}$ & $\begin{array}{l}.847 \\
.772\end{array}$ & .913 & .903 & .789 & .836 \\
\hline $\begin{array}{c}\text { Perceived Service } \\
\text { Quality }\end{array}$ & $\begin{array}{l}\text { Rel. } \\
\text { Emp. } \\
\text { Resp. }\end{array}$ & $\begin{array}{r}.818 \\
.748 \\
.767\end{array}$ & .848 & .863 & .865 & .845 \\
\hline $\begin{array}{l}\text { Customer Patronage of } \\
\text { insurance products }\end{array}$ & $\begin{array}{l}\text { Buy } \\
\text { N/Buy }\end{array}$ & $\begin{array}{l}.743 \\
.981\end{array}$ & .780 & .788 & .615 & .881 \\
\hline
\end{tabular}


In measuring the reliability of the constructs, two methods were used. The first measure examined the factor loading for each indicator of the constructs measured. The result of the factor loadings are presented in the table 3 above. At 5\% level of significance and with the corresponding t-values to all the indicators of all the constructs which are greater than 2 , each indicator has a significant factor loading. More so, they are higher than the benchmarked threshold of 0.7 (Hair et al., 2011). The second measure is Cronbach's $\alpha$. It measures the internal consistency of the scales/items used for each items on the questionnaire. Given the minimum cut off value for Cronbach's $\alpha$ as 0.7 (Nunnally \& Berstein, 1994). As presented in the table 3 above, the Cronbach's $\alpha$ for each construct varies from 0.780 to 0.913 which shows that the scales/items are internally consistent.

The composite reliability (CR) measures the degree to which each construct's indicators represent or explain the latent construct. The value of composite reliability for each construct varies from 0.803 to 0.881 . These are higher than 0.6 benchmark suggested by Tseng et al. (2006). Therefore, to confirm the validity of all the constructs, both Convergent and Discriminant validity methods were checked. Also, the Average Variance Extracted (AVE), which measures the amount of variance captured by the constructs through the indicators in comparison with the amount of variance captured due to the measurement error was calculated.

To check the discriminant validity, the square root of AVE must be greater than the inter-item correlations among constructs as suggested by Fraering and Minor (2006). From tables 2 and 3 above, it can be obtained that the square root of AVE is greater than the inter-item correlations. Therefore, the discriminant validity of all the scales was supported.

To evaluate the convergent validity of the scales, Chen and Hsieh (2011) opine that the value of AVE should be greater than 0.5. From table 3 above, it can be seen that the values of AVE are greater than 0.5 . With these being authenticated, the composite reliability and the value of Cronbach's $\alpha$ for all the indicators were accepted thus, the test instrument was valid and sufficient to generate reliable responses.

Table 4. Model Fit CFA

\begin{tabular}{cccc}
\hline Model fit indices & $\begin{array}{c}\text { Study } \\
\text { Threshold }\end{array}$ & $\begin{array}{c}\text { Recommended } \\
\text { Threshold }\end{array}$ & Decision \\
\hline Chi-Square value: $\mathrm{X}^{2} / \mathrm{df}$ & 2.61 & $<3$ & Acceptable \\
Comparative fit index (CFI) & 0.977 & $>0.95$ & Acceptable \\
Goodness-of-fit index (GFI) & 0.912 & $>0.90$ & Acceptable \\
Adjusted Goodness-of-fit Index (AGFI) & 0.926 & $>0.95$ & Acceptable \\
Root mean square Error of Approx (RMSEA) & 0.066 & $<0.08$ & Acceptable \\
\hline
\end{tabular}


Table 4 represents the fit indexes for the overall model valuation. The results show that there is an acceptable fit between the proposed structural equation model and sample data since all the model fit indices, especially goodness-of-fit index are within the acceptable threshold (Wang et al 2005). After determining the fitness of the proposed model, the next step was to test the hypothesis of the study.

\section{Test of Hypothesis 1}

$\mathrm{H}_{0}$ : Bancassurance referral model has no significant positive influence on customers' patronage of insurance products in Nigeria

$\mathrm{H}_{1}$ : Bancassurance referral model has a significant positive influence on customers' patronage of insurance products in Nigeria

Table 5. Structured Equation Model Result

\begin{tabular}{lcc}
\hline \multicolumn{1}{c}{ Path Description } & $\begin{array}{c}\text { Unstandardized } \\
\text { Path Estimates }\end{array}$ & Remarks \\
\hline $\mathrm{BRM}=>$ Customers' Patronage of insurance products & $.132^{* *}$ & $\mathrm{~S}$ \\
$\mathrm{BRM}=>$ Customer Loyalty & $.515^{* *}$ & $\mathrm{~S}$ \\
$\mathrm{BRM}=>$ Perceived Service Quality & $.401^{* *}$ & $\mathrm{~S}$ \\
$\begin{array}{l}\text { Customer Loyalty => Customers Patronage of insurance product } \\
\text { Perceived Service Quality }=>\text { Customers' Patronage of } \\
\text { insurance products }\end{array}$ & $.413^{* *}$ & $\mathrm{~S}$ \\
\hline
\end{tabular}

As presented in Table 5 above, bancassurance referral model was positively and significantly related to customers' patronage of insurance products $(\beta=.132, p<0.05)$ and to customer loyalty $(\beta=.515, p<0.05)$, and to perceived service quality $(\beta=.401, p<0.05)$. Customer loyalty was positively and significantly related to customers' patronage of insurance products $(\beta=.413, p<0.05)$. Finally, perceive service quality was significantly related to customers' patronage of insurance products $(\beta=.393, p<0.05)$. Based on the result in table 5 above, we accept the alternate hypothesis which states that: bancassurance referral model has a significant positive influence on customers' patronage of insurance products in Nigeria

\section{Test of Hypotheses 2 and 3}

$\mathrm{HO}_{2}$ : Customer loyalty does not significantly mediate the influence of bancassurance referral model on customers' patronage of insurance products in Nigeria.

$\mathrm{H}_{2}$ : Customer loyalty significantly mediate the influence of bancassurance referral model on customers' patronage of insurance products in Nigeria.

$\mathrm{HO}_{3}$ : Service quality does not significantly mediate the influence of bancassurance referral 
model on customers' patronage of insurance products in Nigeria

$\mathrm{H}_{3}$ : Service quality significantly mediate the influence of bancassurance referral model on customers' patronage of insurance products in Nigeria

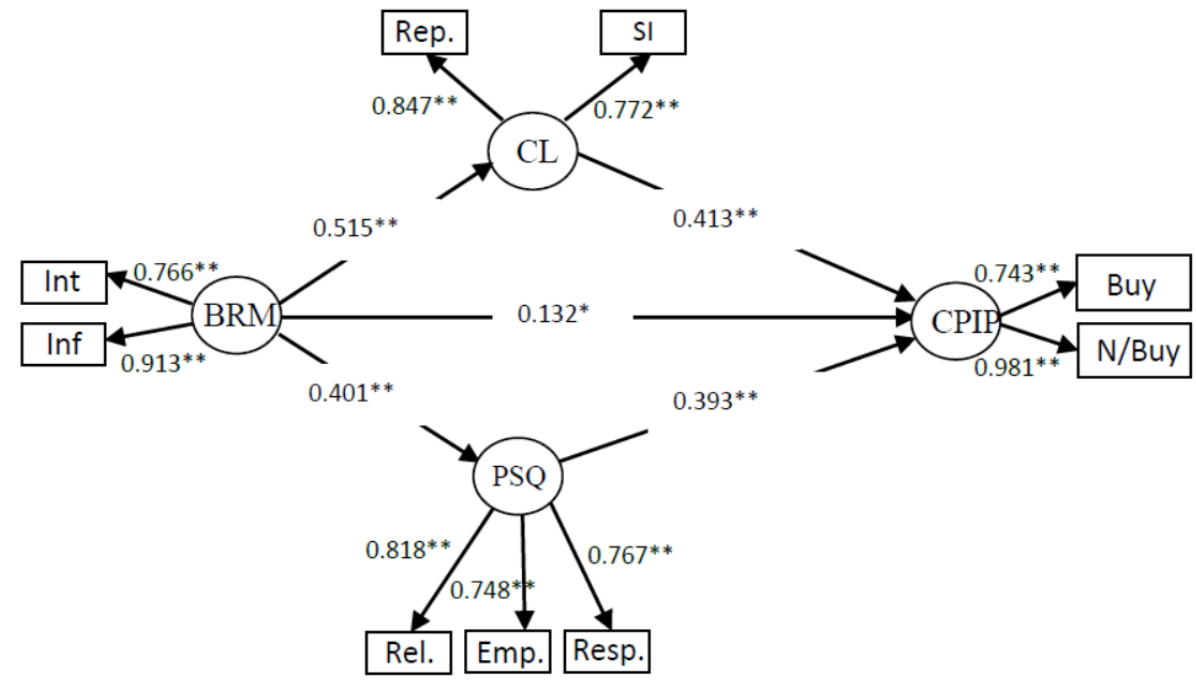

Figure 2. Structural equation model showing hypothesized relationships

\section{Mediation Effects}

From the paths specified in the model (see figure 2), two (2) paths were hypothesized to be mediated by the intervening variables, $\mathrm{M}_{1}$ and $\mathrm{M}_{2}$, (i.e. Customer Loyalty and Perceived Service Quality. By following the procedure of Wan Mohamad et al (2014), the hypothesized mediated paths were split in figures 3 and 4 below.

Figure 3

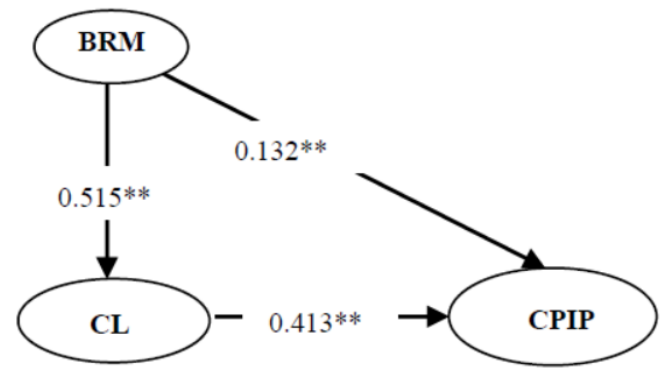

Indirect effect $=0.515 \times 0.413=0.212$ Direct effect $=0.132$

Remark: Significant Partial Moderation
Figure 4

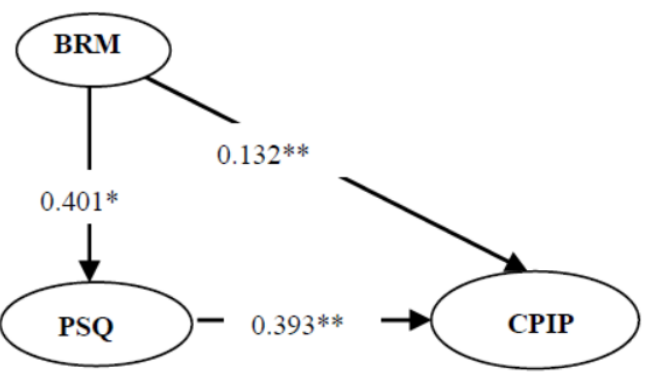

Indirect effect $=0.401 \times 0.393=0.157593$

Direct effect $=0.132$

Remark: Significant Partial Moderation

The foregoing analysis in figure 3 and 4 above summarily indicate that there is though significant connectivity between bancassurance referral model and customers' patronage of insurance products but this is significantly moderated by customer loyalty and perceived service quality of the bank customers. The implication is that, these, intervening variables 
have more influence on the extent to which bancassurance referral model alone can affect the customers' patronage of insurance products.

\section{Summary of findings}

After data analysis, it was discovered that:

1. Bancassurance referral model has a significant positive influence on customers' patronage of insurance products in Nigeria

2. Customer loyalty significantly mediate the influence of bancassurance referral model on customers' patronage of insurance products in Nigeria.

3. Service quality significantly mediate the influence of bancassurance referral model on customers' patronage of insurance products in Nigeria

\section{Discussion of findings and managerial implications}

Findings from this study shows that bancassurance referral model has significant influence on customers' patronage of insurance products in Nigeria. This is in line with the findings of Mwangi (2010) and Genetay and Molyneux (1998) which indicated that bancassurance is an alternative for distributing insurance products. The implication is that insurance managers should capitalize on large customer base and good reputation of deposit money banks in Nigeria to leverage the sales of insurance products.

This study also show that customer loyalty significantly mediate the influence of bancassurance on customer patronage of insurance products in Nigeria. This means that deposit money banks can successfully refer only its loyal customers to insurance companies for business. This is consistent with the findings of Loveline and Sreedevi (2014) which shows that customer loyalty moderate the extent to which banks can successfully refer their customers to insurance products. The implication of this finding to insurance managers is that banks with more loyal customers are likely to do better than those without this strategic advantage. Insurance managers should therefore consider this in choosing deposit money banks to partner with.

This study found service quality as a moderator of the influence of bancassurance on customer patronage of insurance products. This is in line with the findings of Kiragu, (2014) and Loveline and Sreedevi, (2014) who noted that the loyalty and perceived service quality of the banks' customers moderate the extent to which the banks successfully refer their customers to insurance products. The implication is that insurance managers should collaborate with high service quality banks in marketing insurance products to bank customers.

\section{Conclusion}

The CBN's revised bancassurance operational guidelines can work as long as there is an existing good customer loyalty and positive service quality perception from the perspective of the banks' customers. What these invariably means is that, leveraging upon the banks' customer base is not enough for the insurance companies to achieve profitable customer 
patronage through the banks' referral service. The loyalty of the customers together with how positive and qualitative they perceive the service the bank renders to them, will determine the extent to which bancassurance referral model leads to patronage of insurance products.

\section{References}

Ayadi, I (2014). Bancassurance in Tunisia. What are the efficiency gain? International Journal of Financial Research, 5(3).

Brealey, R. A., \& Myers, C. S. (2003). Principles of Corporate Finance (7th ed.). McGraw-Hill Companies.

Casu, B., \& Girardone, C. (2004). Financial Conglomeration: Efficiency, Productivity and Strategic Drive. Applied Financial Economics, 14(10), 687-696.

CBN. (2017). Revised Guidelines on Bancassurance Referral Model. Central Bank of Nigeria.

Chen, H., \& Hsieh, T. (2011). The effect of the atmosphere on consumer perceptions and behaviour responses in chain store supermarkets. African Journal of Business and Management, 5(24), 54-66.

Chen, Z., Li, D., Moshirian, F., \& Tan, J. (2006). Does Bancassurance Add Value to Banks? Evidence from Mergers and Acquisitions between European Banks and Insurance Companies. University of New South Wales, School of Banking and Finance, Mimeo.

Devell, R. F. (1991). Scale Development: Theory and Applications, Applied Social Research Method Series (3rd ed.). SAGE: Newbury Park, C.A.

Fields, L. P., Fraser, D. R., \& Kolari, J. W. (2004). What's Different about Bancassurance? Evidence of Wealth Gains to Banks and Insurance Companies. Mays Business School, Texas A\&M University. Working Paper.

Florido, M. (2002). Bancassurance in Europe. European Journal of Operational Research, 175, 1285-1299.

Fraering, M. A., \& Minor, M. S. (2006). The sense of community: An exploratory study of US consumers of financial services. International Journal of Bank Marketing, 24(5), 284-306.

Genetay, N., \& Molyneux, P. (1998). Bancassurance, London: Palgrave Macmillan.

Hair, J. F., Black, W. C., Babin, B. J., \& Anderson, R. E. (2010). Multivariate data analysis (7th ed.). Upper Saddle River, NJ: Pearson Education Inc.

Igbomirenghian, K. (2010). Experts suggest ways to boost Nigerian insurance industry. Editorial Daily Independent Newspaper, $5^{\text {th }}$ January.

Johri, G. (2009), Consumer satisfaction in general insurance industry. A Journal of Risk and Insurance, 4(6), 66-92.

Jongeneel, O. C. W. (2011). Bancassurance: Stale of Staunch? A Pan- European Country 
Analysis. Unpublished Msc. Economics \& Business Thesis, Erasmus University Rotterdam.

Karimian, A. (2017). The effect of bancassuarnce on bank productivity and profitability evidence from banking industry in Iran. American Journal of Economics, 7(4), 177-185.

Karunagaran, A. (2006). Bancassurance; A feasible Study for Banks in India? Journal of Economics and Sustainable Development, 4(2), 24 -34.

Kiragu, M. (2014). Assessment of Challenges Facing Insurance Companies in Building Competitive Advantage in Kenya: A survey of Insurance Firms. Unpublished Executive MBA Project, JKUAT.

Kotler, P., Bowen, J. T., \& Maken, J. C. (2010). Marketing for Hospitality and Tourism (6th ed.). Upper Saddle River New Jersey: Pearson Education Inc.

Lei, P. W., \& Wu, Q. (2007). Introduction to structural equation modelling: Issues and practical considerations. A NCME Instructional Module, 33-44.

Lovelin, P. A., \& Sreedevi, V. (2014). Preference of Bancassurance. Journal of Business and Management, 16(1), 8-13.

Lovelock, C., \& Writz, J. (2014). Services Marketing: People Technology and Strategy (8th ed.). Boston Pearson Publication.

Mwangi, J. W. (2010). An Assessment of the Determinants of Growth of Bancassurance in Kenya. Unpublished MBA project, University of Nairobi.

NAICOM. (2017). Bancassurance Referral Operational Guidelines. National Insurance Commission.

Nebo, G. N., \& Okolo, V. O. (2014). Effects of the Strategies for customer satisfaction on the performance of insurance firms in Nigeria. IOSR Journal of Business and Management, 18(5), 78-90.

Nunnally, J. C., \& Bernstein, I. H. (1994). Psychometric theory (3rd ed.). New York: McGraw-Hill. In D. Iacobucci, \& Duhochek, A. (2003), Advancing Alpha: Measuring Reliability with Confidence. Journal of Consumer Psychology, 13(4), 478-487.

Parasuraman, A., Zeithal, V., \& Berry, L. L. (1985). A Conceptual Model of Sevrice Quality and its Implications for Future. Research Journal of Marketing, 49(6), 116-143.

Ricci, O. (2012). Studying the Bancassurance Phenomenon: A Literature Review. In F. Fiordelisi, \& O. Ricci (Eds.), Bancassurance in Europe. Palgrave Macmillan Studies in Banking and Financial Institutions. Palgrave Macmillan, London.

Tseng, W. T., Dornye, Z., \& Schmitt, N. (2006). A new approach to assessing strategic learning: The case of self-regulation in vocabulary acquisition. Journal of Applied Linguistics, 27(6), 78-102.

Wang, C. C., Wang, L. C., \& Yang, Y. J. (2005). Innovativeness and mobile phone 
replacement: an empirical study in Taiwan. In Y. U. Ha, Y. Yi, \& M. N. Duluth (Eds.), AP Asia Pacific Advances in Consumer Research. Association of Consumer Research, 6(9), 280-293.

Waweru, T. N. (2014). The Effect of Bancassurance on the Financial Performance of Commercial Banks in Kenya (Unpublished), Master Thesis submitted to School of Business, University of Nairobi.

\section{Copyright Disclaimer}

Copyright for this article is retained by the author(s), with first publication rights granted to the journal.

This is an open-access article distributed under the terms and conditions of the Creative Commons Attribution license (http://creativecommons.org/licenses/by/4.0/). 